\title{
Impact of climatic factors on growth and development of Cichorium Endivia in greenhouse in Leningrad region, Russia
}

\author{
Tatiana A. Lavrishcheva, Anton V. Lavrishchev*, Andrey V. Litvinovich
}

Saint Petersburg State Agrarian University, 196601, Petersburg highway, 2, Saint Petersburg, Russia

*Corresponding author: av.lavrishchev@yandex.ru

\begin{abstract}
The paper discusses the results of the study of the effect of climatic factors on the yield and biometric indicators of various varieties of endive chicory (Cichorium endivia (L.)) over a two-year study grown in the summer-autumn period in the plastic greenhouses on the experimental plots of the St. Petersburg Agrarian University, Pushkin, Russia. The plants of the genus Chicory are known and valued for their unique medicinal and nutritional properties. Total of 14 varieties of domestic and foreign Cichorium endivia breeding were studied. The study was carried out in 2015 and 2016years that were sharply differed in the amount of precipitation and temperature. The climate of Leningrad region is characterised with humid and long-lasting cold season. The aim of the research was to identify the variety of endive chicory that is most suitable and tolerant for the climatic conditions of Leningrad region, Russia. During the growing season the plant biometric parameters such as plant height $(\mathrm{cm})$, rosette diameter of leaves $(\mathrm{cm})$, and number of leaves (pieces) were measured. During harvesting, additional parameters such as biomass of plants and leaves, the area of the assimilation surface were determined. The decrease in plant biometric parameters during the phenological observations in September 2016 was associated with an increased amount of precipitation in JulyAugust. The results showed that the variety "Broad Betavian fullhearted" was the most sensitive to the adverse effects of weather, showing the largest variation in biometrics over the studied years. In plants of this variety the mass of leaves decreased by 9.2 times, the area of the assimilation surface was reduced by 11.6 times, whilethe crop shortfall in 2016 was almost $90 \%$. The varieties "Green curled" and "Scarola bionda" were the most tolerant to weather conditions. These varieties were characterized by the maximum yield in both years of research: "Green curled" $-7.90 \mathrm{~kg} / \mathrm{m}^{2}$ and 2.87 $\mathrm{kg} / \mathrm{m}^{2}$, "Scarola bionda" $-8.06 \mathrm{~kg} / \mathrm{m}^{2}$ and $2.84 \mathrm{~kg} / \mathrm{m}^{2}$ in 2015 and 2016, respectively. Generally, the result of the study showed that most of the studied varieties were sensitive to the amount of precipitation and the number of sunny days. The study made it possible to identify the most sensitive and most tolerant varieties of endive chicory for growing in the Leningrad region.
\end{abstract}

Keywords: endive chicory, precipitation, hydrothermal coefficient, phenology, plant height, rosette diameter, number of leaves

\section{Introduction}

The genus Chicory (CichoriumL.) belongs to the Asteraceae family, the chicory subfamily (Cichorloideae Kitam.). The genus includes 10-12 species, which can be subdivided into two groups (Shevchenko 2000). The first group includes plants capable of forming thickened roots. The representative of this group is the endive chicory witloof ( $C$. Intybus var. Foliosum). The description of the growth and development of various varieties of endive chicory is given in our earlier publication (Lavrishcheva 2020). The second group includes plants with above-ground storage organs. The representative of this group is Chicorium Endivia $(\mathrm{L}$.). The plants in genus Cichorium has 
been used globally from ancient times as a coffee substitute, vegetable crop, and medicinal plant, and were occasionally used as animal forage as well (Aisa et al 2020). The cultivated chicory endive has a history that roots back to ancient Egypt. The Eber Papyrus, dating from $4000 \mathrm{BC}$ is the oldest written document to refer to chicory. Chicory was known to the ancient Egyptians, Romans and Greeks as a medicinal plant, a food product and a source for coffee-like drink made of the roasted chopped chicory roots. The great physician and philosopher of antiquity Avicenna dedicated his "Treatise on Chicory" to this plant. In Europe, this plant was recognized in the 17th century as a drink and food ingredient (Pieroni 2005).

Endive chicory lettuce (Cichorium endivia L.) is an annual or biennial plant of the Asteraceae family. Its leaves contain protein, sugars, ascorbic acid and B vitamins, provitamin A, potassium, calcium and iron salts, as well as valuable substances such as inulin and glycoside intibine, which have a beneficial effect on digestion processes, metabolism, and the activity of the nervous and cardiovascular system (Gusev 1991). The nutritional composition of endive is about per $100 \mathrm{~g}$ edible portion includes water $94 \mathrm{~g}$, protein $1.3 \mathrm{~g}$, fat $0.2 \mathrm{~g}$, carbohydrate $3.4 \mathrm{~g}$, fibre $3.1 \mathrm{~g}, \mathrm{Ca} 52 \mathrm{mg}, \mathrm{Mg}$ $15 \mathrm{mg}$, P $28 \mathrm{mg}$, Fe $0.8 \mathrm{mg}$, Zn $0.8 \mathrm{mg}$, vitamin A $2167 \mathrm{IU}$, thiamin $0.08 \mathrm{mg}$, riboflavin $0.08 \mathrm{mg}$, niacin $0.4 \mathrm{mg}$, folate $142 \mu \mathrm{g}$, and ascorbic acid $13 \mathrm{mg}$ (Grubben and Denton, 2004; Aisa et al 2020).Due to the presence of inulin, it is highly valued in the diet of patients with diabetes mellitus and is a promising crop for growing in the Leningrad region (Lavrischeva 2017; Naida 2018; Lavrischeva, Osipova 2016; Osipova, Lavrischeva 2016; Varan et al 2019). The results of studying various aspects of endive cultivation technology, such as feeding area, planting dates, etc., on morphometric parameters and biochemical composition of plants in the conditions of the Leningrad region are given in our earlier works (Lavrischeva and Osipova 2020; Lavrischeva 2019; Lavrischeva 2019). However, because the endive chicory is a sensitive to climatic conditions culture, studying the effect of weather conditions in the Leningrad region on the growth and development of endive is also a very relevant in order to successful cultivation of this highly valuable medicinal and nutritional plant. The global climate change is predicted to affect the plant growth due to changes in air and soil surface temperatures (Peng et al 2004). The predicted rise in temperature suppose to cause changes in morphological, anatomical, physiological and biochemical characteristics of plants (Wahid et al 2007), as well as may greatly affect plant phenology (Wollenweber et al., 2003; Snider et al., 2009).

The Selyaninov hydrothermal coefficient (HTC) is a useful tool for determining the water status of the environment (Taparauskienè and Miseckaite 2017; Bundere-Evarte and Evarts-Bundersd 2013; Bartoszek and Banasiewicz 2007). The relationship of crop plant development and yield with hydrothermal conditions is based on current or predicted temperature and atmospheric precipitation (Ziernicka-Wojtaszek 2009). The hydrothermal coefficient is used as the primary climate variable (Melkonyan and Asadoorian 2013). Very little research has been published on the biometric characteristics of chicory on response of abiotic factors. Moreover, there are practically no published 
studies on the growth and development of chicory endive in the conditions of north-western Russia. Considering the growing interest in this crop as a valuable source of nutrients and as a medicinal plant, the need to produce this crop in the Leningrad region is very relevant. The successful cultivation and production of chicory endive on a commercial scale is impossible without the preparation of a scientifically sound basis. For this, first of all, it is necessary to select the varieties that will be most adapted to the climatic conditions of north-western Russia, the Leningrad region.

The goal of this work was studying the influence of weather conditions on the yield and biometric indicators of different varieties of endive chicory grown in the summer-autumn terms in plastic greenhouses. The task of the study was focused on the selection of most appropriate variety of endive chicory for successful cultivation in the climatic conditions of the Leningrad region.

\section{Materials and Methods}

\section{Study site and crop varieties}

The study involved 14 endive varieties, from which four varieties are included in the Register of breeding achievements of the Russian Federation: variety "Milady"-the originator of HM. CLAUSE S.A. (France); "Vesenny"- the originator of LLC "Agrofirma Poisk";"Strely Amura"-the originator of LLC "Agrofirma" Sedek " Pala Rossa"- the originator of CJSC "Company LANS". For research, we used the "Pala Rossa" variety produced by the selection and seed-growing company "Gavrish" (Moscow) and the limited liability company "Agronika" (St. Petersburg).Seven varieties of foreign selection (Crespa Finasiempreblanca, Greencurled, Friseed'Olivet, Broad Betavian full-hearted, Cornetd'Anjou, Frisse grosse pommat se, Scarolabionda) were provided by the Russian Research Institute of Plant breeding named after N.I. Vavilov. Three domestic varieties not included in the Register of breeding achievements were "Doctor Diabeta" (NPF "Sedek"); “Nezhny"and "Red Ball”

The study was carried out in 2015 and 2016 years that sharply differed in the amount of precipitation and temperature. Plants were grown in plastic greenhouses on the territory of the educational and experimental garden of the St. Petersburg State Agrarian University (Pushkin town). Sowing was carried out in early July, and the planting on plots of 20 x20size was carried out in early August.

During the growing season (in the first decade of September), the following biometric parameters were determined: plant height, diameter of the rosette of leaves, and the number of leaves per plant. The harvest was carried in October $2^{\text {nd }}(2015)$ and October $4^{\text {th }}(2016)$. During harvesting, the same biometric parameters were determined as during the growing season, as well as the mass of plants, the mass of leaves, the area of the assimilation surface. 


\section{Description of the site climatic and growth conditions}

The climate of the Leningrad region is rather mild with average annual temperature around + $4.5^{\circ} \mathrm{C}$. The movement of air masses of different origin has a huge impact on the climate of the region. Humid Atlantic air comes in from the West, causing rain and sleet. In the summer, this stream causes cool weather with drizzling rains. Continental air coming from the east brings dry weather: in summer with a temperature of $+26+30^{\circ} \mathrm{C}$, in winter - frosty. Arctic air masses from the north and northeast set in the cold and sunny weather. The region is characterized by frequent changes in air masses, therefore, unstable weather. The coldest month is January with an air temperature of $-16-20^{\circ} \mathrm{C}$. The duration of the period with the average daily air temperature above $+5^{\circ} \mathrm{C}$ is 175 days. The number of days in a year with an average daily air temperature above $+10^{\circ} \mathrm{C}$ is 125 days. The warm period lasts 205-220 days. However, frosts are possible until late May - early June.

By the amount of precipitation, the Leningrad Region belongs to the zone of excessive moisture with annual precipitation of $550-600 \mathrm{~mm}$. In some years, the amount of precipitation changes significantly: in a dry year, $350-500 \mathrm{~mm}$ and in the wettest, up to $800-900 \mathrm{~mm}$. The maximum amount of precipitation falls within the two periods: January - February and July September (Rapina 2019). The city of Pushkin is located in the second of the five agro-climatic regions of the Leningrad Region. It is characterized as moderately warm. Data on the distribution of precipitation in the years of study according to the data of the Pushkin meteorological station of the St. Petersburg State Agrarian University (N59 ${ }^{\circ} 44^{\prime} 07.55$ ", E30 ${ }^{\circ} 23^{\prime} 08.05$ ") are given in Table. 1. As can be seen from the data presented, the weather conditions in 2015 and 2016 differed significantly in the amount of precipitation during the growing season of the studied endive chicory lettuce.

The studied plants in the summer-autumn period developed from early July to early October. The amount of precipitation in July was higher than the long-term average values in both years of research: by 34\% in 2015 and almost 3 times in 2016 (288\%). Moisture deficit recorded in August 2015 was $48 \%$ of the long-term average values. The same period of 2016 this parameter was almost doubled (195\%), while September and October were dry in both studied years. The amount of precipitation, depending on the year of research, was in September - 67.7\% and 61.7\%, and in October $36.0 \%$ and $62.4 \%$ of the average long-term values, respectively, for the years of research.

The limiting factor for plant growth and development is a setting of warm temperatures (Nösberger and von Boberfeld). The sum of active temperatures during the growing season of plants and the duration of this period is the main indicator of heat supply. The sum of active temperatures in the territory of the experiment is given in Table 2. 
Table 1. Distribution of precipitation during the growing season by years of research (meteorological station of St. Petersburg State Agrarian University, Pushkin), mm

\begin{tabular}{|c|c|c|c|c|c|c|c|c|}
\hline \multirow{2}{*}{\multicolumn{2}{|c|}{ Years }} & \multicolumn{6}{|c|}{ Months } & \multirow{2}{*}{$\begin{array}{c}\text { Sum forV ...X } \\
\text { mm }\end{array}$} \\
\hline & & $\mathrm{V}$ & VI & VII & VIII & IX & $\mathrm{X}$ & \\
\hline \multirow[t]{2}{*}{2015} & $1 *$ & 48.3 & 29.8 & 108.7 & 41.3 & 36.4 & 23.5 & 288.0 \\
\hline & 2 & +2.3 & -44.4 & +27.6 & -44.5 & -17.4 & -41.7 & - \\
\hline \multirow[t]{2}{*}{2016} & 1 & 16.8 & 73.4 & 233.7 & 167.6 & 33.2 & 40.7 & 565.4 \\
\hline & 2 & -29.2 & -0.8 & +152.6 & +81.8 & -20.6 & -24.5 & - \\
\hline \multicolumn{2}{|c|}{ Annual average } & 46.0 & 74.2 & 81.1 & 85.8 & 53.8 & 65.2 & 406,1 \\
\hline
\end{tabular}

*Note: 1 - amount of precipitation per year; 2 - deviation from mean annual values.

Table 2. The sum of active air temperatures (meteorological station of the St. Petersburg State Agrarian University, Pushkin), ${ }^{\circ} \mathrm{C}$

\begin{tabular}{|c|c|c|c|c|c|c|c|c|}
\hline \multirow[b]{2}{*}{ Years } & \multicolumn{6}{|c|}{ Months } & \multirow{2}{*}{$\begin{array}{l}\text { Sum } \\
\text { forV...X }\end{array}$} & \multirow{2}{*}{$\begin{array}{c}\text { The period } \\
\text { witht }>10^{\circ} \mathrm{C} \\
\text { days }\end{array}$} \\
\hline & $\mathrm{V}$ & VI & VII & VIII & IX & $\begin{array}{c}\text { X } \\
\text { (1-я декада) }\end{array}$ & & \\
\hline 2015 & 340.9 & 493.8 & 538.5 & 563.4 & 398.5 & 61.7 & 2396.8 & 149 \\
\hline 2016 & 437.2 & 488.8 & 614.8 & 559.2 & 389.3 & 35.1 & 2524.4 & 153 \\
\hline
\end{tabular}

As can be seen from the data presented, the sum of active air temperatures in 2015 at the beginning of the growing season (July) was less than in 2016, and the subsequent periods: August, September and the first ten days of October exceeded the values of 2016.

The Selyaninov hydrothermal coefficient (HTC) is used as the primary climate variable, which includes not only precipitation, but also temperature during the vegetation period (Melkonyan and Asadoorian, 2013) and is calculated using the following equation: $\mathrm{HTC}=\Sigma \mathrm{x} / \Sigma \mathrm{t} \times 10$; where $\Sigma \mathrm{x}$ and $\Sigma \mathrm{t}$-accordingly sum of precipitations and temperatures in the period, when the temperature has not been lower than $10^{\circ} \mathrm{C}$ (Selyaninov 1928). The hydrothermal regime based on the obtained HTC is categorized as follows: a zone of excessive moisture, or a drainage zone (HTC> 1.3), a zone of sufficient moisture (1.0-1.3); arid zone (0.7-1.0), a dry farming zone (0.5-0.7), a dry or irrigated zone (GTC <0.5) (Selyaninov 1928).

During the study years, according to the months of vegetation of the endive chicory, the HTC indicator varied greatly (Table 3).In 2015, most of the growing season, moisture was insufficient - in June, August and September the amount of precipitation was $40.2 \%, 48.1 \%, 67.7 \%$ of the long-term average monthly values, respectively. May 2016 turned out to be dry $(\mathrm{HTC}=0.3)$, June was wet, July and August were waterlogged (HTC $=3.1$ and 3.7, respectively), and September was arid (HTC = $0.9)$.

Table 3. Hydrothermal coefficient (HTC) in 2015 and 2016 years (meteorological station of the St. Petersburg State Agrarian University, Pushkin)

\begin{tabular}{ccccccc}
\hline \multirow{2}{*}{ Years } & \multicolumn{5}{c}{ Months } & \multirow{2}{*}{ Average for season } \\
\cline { 2 - 5 } & V & VI & VII & VIII & IX & \\
\cline { 2 - 5 } 2015 & 1.2 & 0.6 & 2.0 & 0.8 & 0.9 & 1.1 \\
2016 & 0.3 & 1.5 & 3.7 & 3.1 & 0.9 & 1.9 \\
\hline
\end{tabular}




\section{Results and Discussions}

The results of studying the influence of weather conditions on some biometric indicators of endive chicory during the growing season are presented in Table. 4. The data indicate that the varieties "Doctor Diabetes", "Pala Rossa" (Agronika) and "Red Ball" during the growing season in 2015 differed in the minimum plant height $-22,22$ and $23 \mathrm{~cm}$, as well as the smallest number of leaves in the rosette: 7.9, 8.6 and 8.4 pieces, respectively. The most compact rosette diameter during the growing season in 2015 was characteristic of the varieties "Doctor Diabeta" $(28 \mathrm{~cm})$ and "Nezhny" $(27 \mathrm{~cm}$ ), and these values were equal to the maximum values of the same indicator in 2016 (Table 4). The greatest height $(47 \mathrm{~cm})$ and diameter of the rosette $(47 \mathrm{~cm})$ was formed during the growing season in 2015 by the "Milady" variety. At the same time, it surpassed all other varieties in these indicators in both years of study.

Table 4. The biometric characteristics of endive chicory during the growing season, in summer-autumn (09.09.2015 and 06.09.2016)

\begin{tabular}{lcccccc}
\hline \multirow{2}{*}{ Variety } & \multicolumn{2}{c}{ Plant height, cm } & Rosette & diameter, $\mathrm{cm}$ & \multicolumn{2}{c}{ Number of leaves, pcs } \\
\cline { 2 - 7 } & 2015 & 2016 & 2015 & 2016 & 2015 & 2016 \\
\hline Doctor Diabeta & 22 & 23 & 28 & 22 & 7.9 & 5.6 \\
Crespa Fina siempre blanca & 27 & 14 & 37 & 24 & 21.7 & 7.7 \\
Green curled & 37 & 22 & 45 & 27 & 25.4 & 11.9 \\
Frisee d'Olivet & 34 & 18 & 41 & 26 & 25.4 & 7.5 \\
Broad Betavian full hearted & 38 & 10 & 45 & 12 & 23 & 3.6 \\
Cornet d'Anjou & 36 & 11 & 38 & 12 & 13.5 & 3.7 \\
Frisse grosse pommat se & 33 & 14 & 38 & 18 & 23.9 & 6.7 \\
Scarola bionda & 33 & 14 & 34 & 18 & 16.3 & 7.4 \\
Milady & 47 & 30 & 47 & 28 & 20.1 & 7.1 \\
Vesenny & 30 & 13 & 40 & 25 & 24.4 & 8.5 \\
Nezhny & 28 & 18 & 27 & 19 & 9.8 & 4.8 \\
Pala Rossa(Gavrish) & 29 & 17 & 39 & 19 & 9.4 & 5.8 \\
Pala Rossa(Agronika) & 22 & 13 & 32 & 19 & 8.6 & 5.9 \\
Red Ball & 23 & 16 & 32 & 17 & 8.4 & 7.5 \\
Strely Amura & 33 & 27 & 33 & 28 & 11.5 & 6.8 \\
\hline LCD & 3.5 & 2.3 & 4.8 & 3.4 & 2.5 & 0.9 \\
\hline
\end{tabular}

The maximum number of leaves was formed in variety "Green curled" and "Frisee d'Olivet" with an index of 25.4 leaves in the first ten days of September 2015, which was significantly higher among all other cultivars in the given observation period, with the exception of "Vesenny" variety (24.4 pieces).

Analysis of the data obtained in 2016 shows that the conditions of the wet year had a significant impact on the biometric parameters of plants. The height of plants during the growing season at the beginning of September 2016, depending on the variety, was 0.9-3.8 times less than that of plants on the same dates in 2015. The only exception was the variety "Doctor Diabeta". The study has shown that the most compact varieties in 2016 were "Broad Betavian" and "Cornet d'Anjou" with the height of 10 and $11 \mathrm{~cm}$, respectively, and the rosette diameters of $12 \mathrm{~cm}$. The values of plant height, rosette diameter and number of leaves in these varieties were significantly lower than in the rest varieties 
grown this year. It should be noted that compared to 2015, the height of plants of the varieties "Broad Betavian fullhearted" and "Cornet d'Anjou" decreased by 3.8 and 3.3 times, the rosette diameter by 3.8 and 3.2 times and the number of leaves by 6.4 and 3.6 times, respectively.

The maximum indicators in height of $30 \mathrm{~cm}$ and $27 \mathrm{~cm}$ and a diameter equal to $28 \mathrm{~cm}$ were for the varieties "Milady" and "Strely Amura". The variety "Green curled" (11.9 pieces) significantly surpassed other varieties in 2016 in terms of the number of leaves, but their number decreased by more than twofold, compared to September 2015.

A decrease in plant biometric parameters during phenological observations in September 2016 was associated with an increased amount of precipitation in July -August, which was the reason for a decrease in the number of sunny days during the period of active growth of the endive. The results of studying the biometric indicators of the endive plants during harvesting are presented in Table 5.

Table 5. The biometric indicators of endive chicory grown in summer-autumn during harvesting (02.10.2015 and 04.10.2016)

\begin{tabular}{lcccccc}
\hline \multirow{2}{*}{ Variety } & \multicolumn{2}{c}{ Plant height, $\mathrm{cm}$} & \multicolumn{2}{c}{ Rosette diameter, cm } & \multicolumn{2}{c}{ The number of leaves, pcs } \\
\cline { 2 - 7 } & 2015 & 2016 & 2015 & 2016 & 2015 & 2016 \\
\hline Doctor Diabeta & 42 & 33 & 34 & 33 & 14.3 & 7.6 \\
Crespa Fina siempre blanca & 38 & 20 & 41 & 27 & 52.3 & 16.8 \\
Green curled & 41 & 34 & 40 & 27 & 51.8 & 40.8 \\
Frisee d'Olivet & 40 & 26 & 47 & 24 & 50.7 & 26.5 \\
Broad Betavian full hearted & 43 & 20 & 52 & 17 & 41.6 & 8.4 \\
Cornet d'Anjou & 49 & 24 & 53 & 21 & 16.7 & 21 \\
Frisse grosse pommat se & 33 & 22 & 38 & 22 & 46.4 & 22.5 \\
Scarola bionda & 40 & 21 & 47 & 21 & 39.1 & 17.8 \\
Milady & 60 & 37 & 52 & 24 & 41.2 & 19.7 \\
Vesenny & 40 & 23 & 50 & 30 & 40.2 & 25.4 \\
Nezhny & 34 & 25 & 48 & 25 & 27.3 & 10.7 \\
Pala Rossa (Gavrish) & 44 & 29 & 56 & 27 & 14.9 & 7.9 \\
Pala Rossa (Agronika) & 24 & 22 & 40 & 28 & 10 & 7.6 \\
Red Ball & 30 & 22 & 45 & 28 & 10 & 8.8 \\
Strely Amura & 53 & 41 & 45 & 28 & 17.3 & 12.6 \\
\hline LCD & 3.5 & 3.9 & 5.3 & 3.6 & 6.9 & 2.3 \\
\hline
\end{tabular}

In 2015, the maximum plant height was recorded for the "Milady" variety $-60 \mathrm{~cm}$, and the minimum - for the "Pala Rossa" (Agronika) variety - $24 \mathrm{~cm}$. Moreover, in both cases, these indicators were significantly different from other varieties. The largest rosette diameter was formed by the varieties "Broad Betavian full hearted", "Cornet d'Anjou", "Milady" and "Pala Rossa" (Gavrish), with indicators of 52, 53, 52 and $56 \mathrm{~cm}$, respectively. The smallest rosette diameter was formed by the varieties "Doctor Diabetes" $(34 \mathrm{~cm})$ and "Frisse grosse pommat seule" $(38 \mathrm{~cm})$. The maximum number of leaves was found in the varieties "Crespa Fina siempre blanca", "Green curled" and "Frisee d'Olivet" (52.3; 51.8 and 50.7 pcs, respectively), and the smallest (10 pcs) - in the varieties "Pala Rossa" (Agronika) and "Red Ball".

Analysis of the 2016 data showed that by the time of harvesting, the plants did not have time to recover from the adverse weather conditions during active growth. The biometric indicators of the 
studied varieties were significantly lower than in 2015. The height of plants decreased by 1.1-2.2 times, the diameter of the rosette - by 1.03-3.1 times and the number of leaves is 1.1-5 times. The exception was the variety "Cornet d'Anjou", which showed an increase in the number of leaves from 16.7 pieces in 2015 to 21 pieces in 2016.

An analysis of biometric indicators between studied varieties showed that the maximum plant height $(41 \mathrm{~cm})$ was recorded in the "Strely Amura" variety, and the minimum $(20 \mathrm{~cm}$ each) in the "Crespa Finasi empreblanca" and "Broad Betavian fullhearted" varieties. The rosette diameter in plants varied from $17 \mathrm{~cm}$ ("Broad Betavian fullhearted") to $33 \mathrm{~cm}$ ("Doctor Diabeta"). Despite the maximally formed rosette, the "Doctor Diabeta" was characterized by the minimum number of leaves (7.6 pieces). The minimum number of leaves was also recorded for the both "Pala Rossa" variety (7.9 and 7.6 pieces), and the significantly maximum value for this indicator (40.8 pieces) was recorded for the "Green curled" variety. It should be noted that "Green curled" showed consistently the highest number of leaves in both study years. This valuable quality, combined with early maturity, synchronicity of the onset of developmental phases and good taste, made it possible to distinguish it among other varieties as the most promising for further research for seed production (Lavrischeva and Osipova 2018).

Table 6. Biometrics and assimilation surface of endive chicory grown in summer-autumn during harvesting (02.10.2015 and 04.10.2016)

\begin{tabular}{|c|c|c|c|c|c|c|}
\hline \multirow{2}{*}{ Variety } & \multicolumn{2}{|c|}{ Leaves weight, g } & \multirow{2}{*}{$\begin{array}{c}\text { Ratio } \\
2015 / 2016\end{array}$} & \multicolumn{2}{|c|}{$\underset{\mathrm{m} 2}{\text { Assimilation surface, }}$} & \multirow{2}{*}{$\begin{array}{c}\text { Ratio } \\
2015 / 2016\end{array}$} \\
\hline & 2015 & 2016 & & 2015 & 2016 & \\
\hline Doctor Diabeta & 44 & 28 & 1.6 & 0.24 & 0.10 & 2.4 \\
\hline Crespa Fina siempre blanca & 298 & 66 & 4.5 & 1.17 & 0.19 & 6.2 \\
\hline Green curled & 309 & 107 & 2.9 & 1.10 & 0.32 & 3.4 \\
\hline Frisee d'Olivet & 247 & 69 & 3.6 & 0.84 & 0.22 & 3.8 \\
\hline Broad Betavian full hearted & 240 & 26 & 9.2 & 0.93 & 0.08 & 11.6 \\
\hline Cornet d'Anjou & 266 & 61 & 4.4 & 0.97 & 0.21 & 4.6 \\
\hline Frisse grosse pommat se & 185 & 76 & 2.4 & 0.65 & 0.23 & 2.8 \\
\hline Scarola bionda & 304 & 106 & 2.9 & 1.07 & 0.27 & 4.0 \\
\hline Milady & 257 & 88 & 2.9 & 0.93 & 0.30 & 3.1 \\
\hline Vesenny & 247 & 59 & 4.2 & 0.90 & 0.17 & 5.3 \\
\hline Nezhny & 226 & 76 & 3.0 & 0.75 & 0.24 & 3.1 \\
\hline Pala Rossa (Gavrish) & 258 & 59 & 4.4 & 0.67 & 0.15 & 4.5 \\
\hline Pala Rossa (Agronika) & 153 & 54 & 2.8 & 0.31 & 0.16 & 1.9 \\
\hline Red Ball & 203 & 64 & 3.2 & 0.68 & 0.20 & 3.4 \\
\hline Strely Amura & 69 & 50 & 1.4 & 0.30 & 0.16 & 1.9 \\
\hline
\end{tabular}

An important criterion for growing salad crops is the mass of leaves formed by the beginning of harvesting (Lavrishcheva 2019). The maximum leaf mass was formed by the varieties "Green curled" and "Scarola bionda" (309 g and $304 \mathrm{~g}$ in 2015, and $107 \mathrm{~g}$ and $106 \mathrm{~g}$ in 2016, respectively) (Table 6). The above varieties also had a high assimilation surface area $\left(1.10 \mathrm{~m}^{2}\right.$ for "Green curled" and $1.07 \mathrm{~m}^{2}$ for "Scarola bionda"). Only the "Crespa Fina siempre blanca" in 2015 and "Milady" in 2016 managed to get better surface area indicators that were $1.17 \mathrm{~m}^{2}$, and $0.30 \mathrm{~m}^{2}$, respectively. All varieties in 2016 
reduced the area of the assimilation surface from 1.9 times ("Pala Rossa" (Agronika) and "Strely Amura"), to 11.6 times ("Broad Betavian fullhearted"). Compared to 2015, the weight of the leaves also decreased (from 1.4 times for the "Strely Amura" to 9.2 times for the "Broad Betavian fullhearted"). The yield data for the endive plants for the studied years are presented in Figure 1.

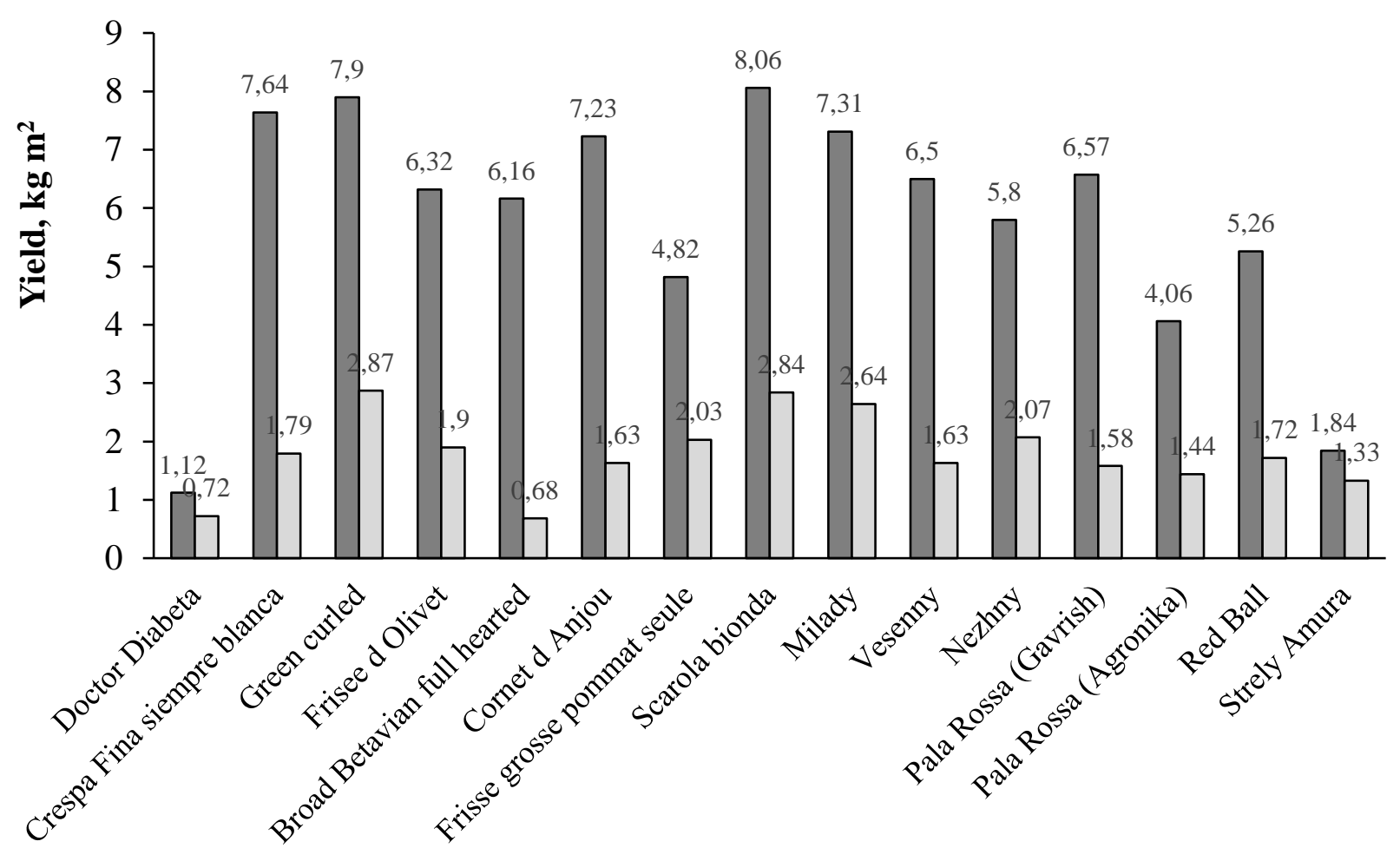

Varieties of chicory

Figure 1. Yields of the endive varieties grown during the research years (2015 and 2016)

The research results indicate that the weather conditions in 2016 negatively affected the yield of the green mass of plants. Compared to 2015, the yield of plants grown in 2016 decreased by 1.38 9.06 times. The variety "Broad Betavian fullhearted" was the most unstable to unfavourable weather conditions, which reduced plant productivity by 9.06 times. In contrast, the varieties "Green curled" and "Scarola bionda" were the most tolerant to changes in weather conditions. These varieties were characterized by the highest yield in both years of research. The process in establishing stable plant populations and is regulated by many environmental factors (Watt et al 2011; Atashi et al., 2015; Juan-Vicedo et al., 2016). Similarly to our results, Radzka et al (2015) found that potato yield was significantly affected by the hydrothermal conditions and exerted more impact on early potato yields particularly during the second part of the growing season. Generally moisture shortage induces more rapid ripening the plants (e.g., Maletić and Jevdjović, 2003). In our study, opposetily, due to the abnormal humid conditions and shortage of sunny days during the vegetation period, the ripening of chicory endive was prolonged, which resulted in the decreased yield. Kalinová et al. (2002) also 
reported that extreme climatic factors could stop seed development. Although in their study it was associated with drought and high temperatures, we can assume that any sharp fluctuation in hydrothermal coefficient may adversely affect the growth of plants. Japanese researcher found that although biometric characteristics of buckwheat positively correlated with air temperature, the number of pollinated flowers negatively correlated with daily precipitation amount (Inoue et al., 1998).

There are no published information by other researches except our earlier studies on the response of the chicory endive to abiotic factors such as temperature, humidity and duration sunny days. However, a large number of studies on the influence of the hydrothermal coefficient and climatic factors on the growth and development of other plants agree that excessive fluctuations in temperature and precipitation have different effects on different phases of plant growth and development (e.g., Zervoudakis et al., 2012; Romanovskaja et al., 2016; Vahabinia et al 2019; Maksimović et al., 2020). So, Maksimović et al (2020) studying the effect of light on morphological and physiological characteristics of peas reported that intensity of transpiration decreased with decreasing illumination due to decrease in the number of stomatal cells. Their results showed that lower light treatment had an inhibitory effect on the photosynthetic pigment content. So, the light conditions can affect plant morphology, reduce leaf specific gravity and increase surface area (Zervoudakis et al., 2012). Romanovskaja et al (2016) found that the hydrothermal conditions during summer had no effect on the variation of 1000 grains mass of buckwheat varieties, but hydrothermal conditions of an individual summer months had different impact on buckwheat production formation.

\section{Conclusions}

Generally, the result showed that studied varieties of endive chicory were sensitive to the amount of precipitation and the number of sunny days. In July 2016 the amount of precipitation was three-fold, and in August two-fold higher than the long-term average values. This was the reason for the decrease in the number of sunny days during the period of active growth of the endive, which led to a decrease in the yield of the endive in the summer-autumn period. The decrease in plant biometric parameters during phenological observations in September 2016 was associated with an increased amount of precipitation in July-August.

The variety "Broad Betavian fullhearted" proved to be the most sensitive to the adverse effects of weather, showing the largest variation in biometrics over the studied years. In plants of this variety the mass of leaves decreased by 9.2 times, the area of the assimilation surface was reduced by 11.6 times. The crop shortfall in 2016 was almost 90\%. The varieties "Green curled" and "Scarola bionda" were the most tolerant to weather conditions. These varieties were characterized by the maximum yield in both years of research: "Green curled" - $7.90 \mathrm{~kg} / \mathrm{m} 2$ and $2.87 \mathrm{~kg} / \mathrm{m} 2$, "Scarola bionda" - 
$8.06 \mathrm{~kg} / \mathrm{m} 2$ and $2.84 \mathrm{~kg} / \mathrm{m} 2$ in 2015 and 2016, respectively. The study made it possible to identify the most sensitive and most tolerant varieties of endive chicory for growing in the Leningrad region

\section{References}

Aisa HA, Xin X-L, Tang D. 2020. Chemical constituents and their pharmacological activities of plants from Cichorium genus. Chinese Herbal Medicines. 12(3):224-236. https://doi.org/10.1016/j.chmed.2020.05.001

Atashi S, Bakhshandeh E, Mehdipour M, Jamali M, Teixeira Da Silva JA. 2015. Application of a hydrothermal time seed germination model using the Weibull distribution to describe base water potential in zucchini (Cucurbita pepo L.). Journal of Plant Growth Regulation 34:150157 DOI 10.1007/s00344-014-9452-y.

Bartoszek K., Banasiewicz I., 2007. Agrometeorological characteristics of the vegetation period in 2005 against the background of the period of 1951-2005 in the Lublin region. Acta Agroph. 9(2), 275-283.

Čirkovs J. 1978.Lauksaimniecības metroloǵijas pamati. Rīga. Zvaigzne. 186.

Evarte-Bundere G., Evarts-Bunders P. 2012. Using of the Hydrothermal coefficient (HTC) for interpretation of distribution of non-native tree species in Latvia on example of cultivated species of genus Tilia. Acta Biol. Univ. Daugavp., 12 (2): 135 - 148.

Grubben G. J. H., Denton O. A. Ed. (2004). Plant resources of Tropical Africa, vegetables. PROTAFoundation, Wageningen, Netherlands, Earthprint Limited.

Gusev A.M. 1991. Chicory salads endive and escariol. In Healing vegetable plants. Moscow, Publishing House of the Moscow Agricultural Academy, pp 142-144

Juan-Vicedo J, Fernández-Pereira J, Ríos S, Casas JL, Martín I. 2016. Seed germination and storage behaviour of lapiedra martinezii (amaryllidaceae). Seed Science and Technology 44(1):199206 DOI 10.15258/sst.2016.44.1.02.

Inoue N., Hagiwara M. Kim H.Y., Matano T.A. 1998. Preliminary study for modeling seed production in common buckwheat. Fagopyrum 15: 35 - 41.

Kalinová J., Moudrý J., Čurn V. 2002. Technological quality of common buckwheat (Fagopyrum esculentum Moench.). Rostlinna vyroba 48(6): 279-284.

Lavrischeva T.A. 2017. Comparative evaluation of varieties of lettuce chicory endive in springsummer in the plastic greenhouses of the Leningrad region. BulletinoftheSt. PetersburgStateAgrarianUniversity 1(46):31-36

Lavrischeva T.A. 2019. Influence of the food area on the biochemical composition of endive lettuce at different planting dates. Bulletin of the St. Petersburg State Agrarian University 4(57):22-27

Lavrischeva T.A. 2019. Influence of the food area on the productivity of endive lettuce at different planting dates. Bulletin of St. Petersburg State Agrarian University 3(56):24-31 
Lavrischeva T.A. 2020. Influence of the duration of cultivation on the growth and development of various varieties of lettuce chicory (Cichoriumintybus L. var. Foliosum). Bulletin of the St. Petersburg State Agrarian University 2(59):14-21.

Lavrischeva T.A., Osipova G.S. 2016. Comparative assessment of varieties of chicory lettuce in plastic greenhouses of the Leningrad region. Proceedings of the young scientists and students conference "The role of young scientists in solving urgent problems of the agro-industrial complex". pp 38-40

Lavrischeva T.A., Osipova G.S. 2018. Influence of treatments with Epin-extra on biometric indicators and productivity of endive plants. Bulletin of the St. Petersburg State Agrarian University 4(53):21-27.

Lavrischeva T.A., Osipova G.S. 2020. The accumulation of pigments by leaves of endive lettuce (Cichoriumendivia L.) depending on the feeding area and planting dates. Bulletin of the St. Petersburg State Agrarian University 1(58):20-25.

Maksimović T., Janić N., Lubarda B. 2020. Impact of the varying intensity light on some morphoanatomical characteristics and physiological parameters in young plants of Pisum sativum L. Zemljiste i Biljka, 69(1):46-55, http://www.sdpz.rs/images/casopis/2020/zin 69 1 66.pdf

Maletić R., Jevdjović R. 2003. The influence of meteorological conditions on major quantitative and qulitative traits of buckwheat (Fagopyrum esculentum Moench.). - Journal of Agricultural Sciences 48(1): 11-19.

Melkonyan M., Asadoorian O. 2013. Climateimpact on agroeconomy insemiarid region of Armenia. Environment Development Sustainable. Availableathttps://www.unidue.de/imperia/md/content/geographie/klimatologie/environment_sustainable_development.pdf

Naida N.M. 2018. Some features of the growth and development of common chicory in the conditions of the Leningrad region. News of the St. Petersburg State Agrarian University,1(50):11-17

Nösberger J., Opitz von Boberfeld W. 1986. Gruenfutterproduktion . Verlag PP, Berlin und Hamburg, pp 181

Osipova G.S., Lavrischeva T.A. 2016. Agrobiological evaluation of varieties of chicory lettuce in the autumn turnover of plastic greenhouses of the Leningrad region. Bulletin of the Saint Petersburg State Agrarian University 45:25-29

Peng S., Huang J., Sheehy J.E., Laza R.C., Visperas R.M., Zhong X., et al. 2004. Rice yields decline with higher night temperature from global warming. Proc Natl Acad Sci USA, 101:1108-13.

Pieroni A. 2005. Prance, Ghillean; Nesbitt, Mark (eds.). The Cultural History of Plants. Routledge. p. 40. ISBN 0415927463.

Radzka E., Rymuza K., Lenartowicz T. 2015. Analysis of hydrothermal conditions and their impact on early potato yields. Journal of ecological Engineering 16(2):120-124. 
Rapina O.G. 2019. The effect of seed inoculation with promising strains of nodule bacteria (Sinorhizobiummeliloti) on the productivity of alfalfa in the Leningrad region. $\mathrm{PhD}$ thesis: 06.01.01, St Petersburg pp 124.

Romanovskaja D., Razukas A., Asakaviciute R. (2016). Impact of Hydrothermal Conditions on Common Buckwheat (Fagopyrum Esculentum Moench.) Productivity. Applied Ecology and Environmental Research 14(2): 137-150

Selyaninov G.L. 1928. About the agricultural evaluation of the climate. TrudyGGO, 20:177-185. (in Russian)

Shevchenko Yu. P. 2000. Breeding of chicory lettuce endive (Chicoriumendivia L. var. Crispum.), Escariola (Cichoriumendivia L. var. Latifolium Lam.) and witloof (Cichoriumintybus L. var. FoliosumHegi) for yield, product quality and early maturity: $\mathrm{PhD}$ thesis: 06.01.05, Moscow, pp 157

Snider J.L., Oosterhuis D.M., Skulman B.W., Kawakami E.M. 2009. Heat stress-induced limitations to reproductive success in Gossypium hirsutum. Physiol Plant 137:125-38

Taparauskienè L., Miseckaite O. 2017. Comparison of watermark soil moisture content with $\begin{array}{llll}\text { selyaninov hydrothermal } & \text { coefficient. }\end{array}$ AGROFOR :106-115, DOI:10.7251/AGRENG1702106T

Varan G., Varan C., Bilensoy E. 2019. Plant-based natural polymeric nanoparticles as promising carriers for anticancer therapeutics. Chapter 14 in 2Polimeric Nanoparticles as a promising tool for anti-cancer therapeutics, pp 93-318. Kesharwani, Paknikar KM, Gajbhiye V (eds), Elsevier https://doi.org/10.1016/C2018-0-01568-6

Vahabinia F., Pirdashti H., Bakhshandeh E. 2019. Environmental factors' effect on seed germination and seedling growth of chicory (Cichorium intybus L.) as an important medicinal plant. Acta Physiologiae Plantarum 41(27): DOI https://doi.org/10.1007/s11738-019-2820-2

Wahid A., Gelani S., Ashraf M., Foolad M.R. 2007.Heat tolerance in plants: an overview. Environ Exp Bot 67:199-223.

Watt M.S., Bloomberg M, Finch-Savage WE. 2011. Development of a hydrothermal time model that accurately characterizes how thermoinhibition regulates seed germination. Plant, Cell and Environment 34:870-876

Wollenweber B., Porter J.R., Schellberg J. 2003. Lack of interaction between extreme high temperature events at vegetative and reproductive growth stages in wheat. J Agron Crop Sci 189:142-50.

Zervoudakis G., Salahas G., Kaspiris G., Konstantopoulou E. 2012. Influence of light intensity on growth and physiological characteristics of common sage (Salvia officinalisL.) Brazilian Archives of Biology and Technology, 55 (1):89-95

Ziernicka-Wojtaszek A. 2009. Verification of agro-climatic regionalisation types in Poland in the light of contemporary climate change. Acta Agroph., 13(3), 803-812. 


\title{
Утицај климатских услова на раст и развој CichoriumEndivia(L) у лето-јесен у пластеницима у Лењинградској области, Русија
}

\author{
Tatiana Lavrishcheva, Anton Lavrishchev*, Andrey Litvinovich
}

Saint Petersburg State Agrarian University, 196601, Petersburg highway, 2, Saint Petersburg, Russia

*Corresponding author: av.lavrishchev@yandex.ru

\section{Извод}

У раду је проучавана осетљивост различитих сорти цикорије ендивије (Cichorium Endivia (L) на климатске факторе. Током 2015. и 2016. године, 14 сорти биљака цикорије ендивије узгајано је у летњејесењем периоду у пластеницима Државног Аграрног Универзитета Санкт Петербурга. Упоређене сорте су биле домаћег и страног узгоја. Испитивани параметри били су принос и биометријски показатељи, као што су висина биљке, пречник розете лишћа, број листова по биљци, маса биљака, маса листова и површина асимилационе површине. Биљке из рода цикорије су познате и цењене по својим јединственим лековитим и хранљивим својствима. Клима Лењинградске области карактерише влажна и дуготрајна хладна сезона. Циљ истраживања био је да се идентификује врста ендивије цикорије која је најприкладнија и најтолерантнија за климатске услове Лењинградске области у Русији. Генерално, резултат студије показао је да је већина испитиваних сорти била осетљива на количину падавина и број сунчаних дана. Смањење биљних биометријских параметара током фенолошких посматрања у септембру 2016. било је повезано са повећаном количином падавина у јулу и августу. Резултати студије омогућили су нам да идентификујемо најосетљивије и најтолерантније сорте ендивије цикорије.

Кључне рећи: цикорија ендивије, падавине, хидротермални коефицијент, фенологија, висина биљке, пречник розете, број листова 